Article

\title{
Negotiating Journalistic Professional Ethos in Nordic Business Journalism
}

\author{
Johanna Suhonen \\ Media and Communication Studies, University of Helsinki, Finland; johanna.I.suhonen@helsinki.fi
}

Submitted: 28 April 2021 | Accepted: 8 October 2021 | Published: 20 January 2022

\begin{abstract}
News work conducted more like business creates clashes between the journalistic and managerial professional ethos of editors. While journalists' professional ethos includes values of self-regulation, autonomy, and public service, managerialism promotes business ideals, measurable outcomes, and organizational efficiency-values that business journalism is claimed to support. This article aims to show how editors negotiate their work-related ethos at the junction of two professional discourses. The article is based on 20 semi-structured interviews of editors in four Nordic business newsrooms. The results reveal a new hybrid professional ethos that combines managerial practices with journalistic ideals. Furthermore, editors in business journalism tend to absorb managerial tendencies more easily due to close connection to financial and commercial communities. Strong journalistic principles prevail, but managerial ideals are considered a notable part of the new editorial work ethos.
\end{abstract}

\section{Keywords}

business journalism; editor; ethos; financial journalism; managerialism; newsroom management; professionalism

\section{Issue}

This article is part of the issue "New Forms of Media Work and its Organizational and Institutional Conditions" edited by Salla-Maaria Laaksonen (University of Helsinki) and Mikko Villi (University of Jyväskylä).

(C) 2022 by the author(s); licensee Cogitatio (Lisbon, Portugal). This article is licensed under a Creative Commons Attribution 4.0 International License (CC BY).

\section{Introduction}

The digitalization of news media has put newsrooms face to face with changing work practices. As newsrooms implement new technologies and meet a digital audience's preferences, normative journalistic ideas are also reformulated. Editors managing the news work are leading the change in newsrooms and tackling the demands of more efficient, quantified news production. Here, I examine how editors, in the rarely researched domain of business journalism, describe their work practices and ethics in the changing climate where business ideals are more prominent.

In journalism research, observing the construction of professional identity has focused on the profession's value system and shared understanding of being a good journalist (e.g., Deuze, 2007; Kunelius \& Ruusunoksa, 2008; Wiik, 2010). This construction is not static or defined and it closely connects with the profession's work practices, though certain ideas are considered elements of "real journalism"; journalists perceive themselves as impartial and autonomous professionals in the service of the public good (Deuze, 2007, pp. 162-164). Moreover, journalists' attitudes and values are affected by national media systems (Hallin \& Mancini, 2003), and different specialized areas, like business journalism, tend to have their own nuances (e.g., Butterick, 2015; Orange \& Turner, 2013; Reunanen \& Koljonen, 2018; Slaatta \& Kjær, 2007).

The ethos of journalists, i.e., practice-related work ethic, consists of the normative evaluations of good work that relate with the need and capability to do work well (Sennett, 2008, pp. 241-254). Ethos as a concept gathers work practices that are done for "good" but also decodes how changing practices subtly alter professional ideals (Carpentier, 2005; Deuze, 2007, pp. 162-163; Kantola, 2013 , p. 611). Modifications in practices are reflected in journalistic professional identity and the virtues appreciated within the profession. Professional ethos lets us speak both about what journalists want to be and how they must be because of external influences (Hanitzsch \& Vos, 2017; Jaakkola et al., 2015; Kantola, 2013, 2016; Reunanen \& Koljonen, 2018). 
Journalism as a profession makes its claim on occupational authority by distancing itself from business considerations (Schudson \& Anderson, 2009); particularly in newspapers, there has been a Chinese wall between businesspeople and journalists to prevent content being corrupted by commercial interests (Aris \& Bughin, 2009, p. 346). Because journalism is characteristically defined by everyday work processes and routines, not official qualifications, keeping the wall up has been an important and delicate issue (Kantola, 2016, p. 430), but as news outlets meet a harsher economic environment, managerial thoughts and ideas spread from the business to the editorial side. In this situation, the role of editorial leadership is crucial. Maneuvering in the relentlessly changing news media sphere increases demand for business competence within organizations (Achtenhagen \& Raviola, 2007; Gade, 2008).

In this article, I study how managerial work practices are combined with journalistic ones in the work of editors of Nordic business news. This is done to observe how managerial and journalistic professional ideals are negotiated to create a new professional ethos-a conception of who they want to be but also need to be in their work.

Looking at the tension between journalism and managerialism in business journalism is particularly interesting since the field, with its close relations to the commercial and financial life, has been observed to promote neoliberal ideals and uncritically popularizing "enterprise culture," "managerialism" and "cult of the chief executive" (Butterick, 2015; Mazza \& Alvarez, 2000; Slaatta \& Kjær, 2007). Furthermore, the question of whether business journalists are more part of the business society than of journalism has been presented (Doyle, 2006; Engwall \& Kipping, 2002). These questions have gained new meaning in recent decades, when businesses and market forces, natural subjects for business journalists, have obtained ever more power in society (Butterick, 2015, p. 180).

Though the editors' changing professional values and ideals have been studied before, separately or in comparison with reporters, (e.g., Kunelius \& Ruusunoksa, 2008; Waldenström et al., 2019) I chose to concentrate on the news managers' perspective. The editors' perspective on the development of journalism is significant, as their role in newsrooms and power over journalistic content expands (e.g., Deuze, 2005, 2007; Kantola, 2013, 2016). This matter should be examined continuously, as the fast pace of change affects news work daily, and its practices are in constant negotiation with the surrounding environment.

The study, conducted from March to June 2018, draws from a round of 20 semi-constructed interviews with editors in four leading Nordic business newsrooms that provide a comprehensive but somewhat homogenous subject matter within the Nordic media system. The interviews show how editors negotiate new work practices in their ideals of a job well done.

\section{Literature Review: Journalism Meets Managerialism}

Predominantly, ethos is used to describe distinctive virtues, styles of behavior, or informed practices, aimed at achieving the good, or at least some vision of the good. It is an action-oriented concept, opposite to values that might remain unlived or inactive (Aristotle, 1991, p. 37; Maclntyre, 1984, pp. 188-191). Professional ethos describes practice-related work ethics of journalism and is similar to other concepts, like professional identity (see Carpentier, 2005; Deuze, 2005; Hanitzsch et al., 2016) in how it enables observing and separating normative ideals from descriptive practice, seeing journalists as how they want and must do their work (see also Hanitzsch \& Vos, 2017; Jaakkola et al., 2015; Kantola, 2013, 2016; Reunanen \& Koljonen, 2018).

According to Deuze (2007, pp. 162-164), the ideal qualities in journalism are public service, objectivity, autonomy, immediacy, and finally ethics. Such qualities usually characterize journalism in Western societies, though they are not static, but exist in relation to time, surrounding societies, and media systems. Journalism conducted according to these norms, or "professionally," is usually seen as the best kind for democracy, but these qualifications of professional journalism have gathered critical voices too: They are said to make journalism "blunt," constrain its real potential for public service, and be a construction of commercial media and journalists to gain social prestige (Waisbord, 2013).

Earlier research has shown the changing nature of journalists' ideals and value-related work practices (e.g., Kantola, 2013; Reunanen \& Koljonen, 2018) and that there is growing misalignment between ideals and practice: what journalists say and how they practice their work (Wiik, 2015). Journalism cannot be seen as one cohesive profession anymore as younger journalists' experiences differ evidently from the ones of earlier generations; older journalists struggle to hold onto professional values, while for the younger, "liquid" generation, the changes are easier to accept (Kantola, 2013; Nikunen, 2014; Wiik, 2015). There is no clear sense of professional community anymore, which is likely to polarize the profession ideologically; for instance, professional autonomy seems to be reserved for a few high-profile journalists, not regular reporters (Wiik, 2015.). In addition, specialized journalists, like cultural or business journalists, differ from the general.

In the financially tightened market situation, journalists, once seen as free riders of the news business (Aris \& Bughin, 2009, p. 351), have been obliged to defend media organizations' success. In many cases, the walls between news and commercial departments have lowered; consequently, journalists must closely consider audience demands and preferences (Picard, 2006, pp. 6-7) and increasingly take over roles such as news producer (Kantola, 2013, p. 610). The professional ideals of journalistic autonomy and public service might be threatened by shrinking economics (Schudson, 
2009, p. 370) and journalism being conducted more consciously (Hujanen, 2008; Kunelius \& Ruusunoksa, 2008). In this change, newsroom managers are at the forefront. They need to carry out the transformation needed to cope with a new market situation. The journalists' collective, accustomed to work by gut feeling (Schultz, 2007) and independently in the public interest, is now being faced by ever more influential top-down managerial practices: business ideals and performance indicators, a logic of linear control, and a demand for efficiency (Waldenström et al., 2019).

"Managerialism" perceives management as its own profession: According to managerial discourse, there are more similarities than differences between organizations, so all "businesses"-manufacturing, health care, academics, and journalism - can be managed with the same principles. Skills and experience related to an organization's primary business are believed to be secondary. (Klikauer, 2015, p. 1104). According to Entemann (1993), managerialism, with its aim for profitability and efficiency, has become the prevalent ideology of society.

Managerialism has its origins in the growth of neoliberalism, regarded by the economistic view of the world as a marketplace, where free-market principles are fundamental (Maringe, 2010). In the 1980s, belief in free markets' advantages gained ground, and the role of regulation decreased. This was the golden age of business journalism as well. Practical manifestations of managerialism are adoption of a rational business-like approach (e.g., strategic planning and objective setting) and establishing a management culture, strengthening management functions like performance management, adapting human resource management methods to ensure employee commitment, shifting from inputs and processes to outputs and outcomes, and adding more measurements and quantification of outputs as performance indicators (Diefenbach, 2009; Pollitt, 2003; Shepherd, 2018, p. 1662). Similarly, Shepherd (2018) has described five notions of managerialism: in "ideal" managerialism, management is perceived as a good and important thing, a discrete function, value-neutral and rational, and generic and universally applicable; further, managers should have the right to manage.

Managerialism, like professionalism, is a normative system regarding what counts as valuable knowledge, who has access to it, and who is authorized to act on it (Clarke et al., 2000). Managers are professionals of efficiency. Managers are also seen as the main sponsors and beneficiaries of managerialism since it improves their social status organizational position. Therefore, managers may cite the code of good management practice to defend their own autonomy similar to how journalists refer to journalistic integrity (Pollitt, 2003).

Managerialism is challenging journalism just as it challenged academic work (Abramov, 2012; Shepherd, 2018). It may appear to solve the current challenges of journalism and legitimize it with the argument of financial sustainability: In order to produce good-quality journalism, journalists need to accept economic factors, audience orientation, and collaboration with businesspeople (Andersson \& Wiik, 2013; Cornia et al., 2020; Waldenström et al., 2019, p. 5). Furthermore, journalists see their managers' right to lead as a necessity for their company to survive; contrary to earlier times, when newsrooms were supervised by collegial control, the responsibility is now given increasingly to editors, who focus more on measurable outcomes than input and process of news production (Waldenström et al., 2019). Not all accept these changes. Andersson and Wiik (2013) suspect there is a risk of journalistic values becoming superficial-constantly being applauded but with no influence on editorial decisions.

To put it bluntly, managerialism does not care what kind of journalism is produced, it concentrates on efficient production and preferred outcomes, which might challenge the ideals of journalism. Journalists have seen public service and commercial goals as opposite objectives and perceived these as a zero-sum game. This could be a maneuver to protect the autonomy of the profession and to gain trust and credibility, a great social asset to journalists. In this mindset, the newsroom produces all the news organization's value, and commercial departments only exploit it, borrowing the credibility and readers' trust (Coddington, 2015). However, research indicates that journalistic and managerial logic may coexist (Saldaña et al., 2016). Raviola (2017) describes how editors appeal to both traditional journalistic values and financial principles and, depending on the situation, make choices accordingly. Additionally, Cornia et al. (2020) show that there is a new norm of integration between editorial and commercial functions that combines journalistic ideals with values such as collaboration, adaptation, and business thinking. Managerial ideals and work practices streamline particularly editorial work, and as Andersson and Wiik (2013) notice, make editors experience their role as more professionalized than earliernot in the journalism field, but with economic and managerial skills.

\section{Business Journalism as a Profession}

Over the last 50-60 years, business and economic media coverage have increased considerably, following the growing importance of economic factors in daily life. However, research on business journalism remains limited. Earlier research concentrated on historical development, and more recently it has broadened its outlook to the field's relationship with stakeholders, and geographical perspective has shifted to more regional and to markets outside Anglo-Saxon countries (Slaatta \& Kjær, 2007, pp. 13-26).

Business journalists are a specialist group with some practices of their own, although the line towards general journalism is not static (e.g., Ainamo et al., 2006). Doyle (2006) even claims that business journalists commonly see themselves as professionals of the business 
community while the role of journalists is somewhat subordinate to it. Indeed, business journalism has always connected closely with stakeholders of commercial and financial life in surrounding society, and business journalists tend to position themselves to assist investors, managers, and other parties that need market-relevant information (Davis, 2007, pp. 64-65). Furthermore, business journalism has been claimed to play a part in spreading and commercializing certain ideals of management, and Engwall and Kipping (2002) even see business media as part of a symbiotic system, the "global management knowledge industry." Observers fear that business journalism uncritically popularizes "enterprise culture" and "managerialism" (Mazza \& Alvarez, 2000), and, for instance, Tienari et al. (2007) show how by discursive framing, business journalists highlight certain neoliberal translations of social reality while marginalizing others.

Particularly after the 2008 financial crisis, business journalists have been accused of forgetting their ideals and role as a watchdog of society's financial and commercial power. In general, business journalism accepts and helps sustain a neoliberal view of business and the hegemony of free-market capitalism (Butterick, 2015, pp. 127, 174) which might be contradicting when reporting on the economy broadly, not just on companies. In addition to being too close to their sources, business journalists are claimed to be economically illiterate to report objectively on market movements and too focused on short-term trends leading to a reinforcement of the market consensus (Schiffrin, 2015; Thompson, 2013).

In her study on American business journalists, Strauß (2019) notes that business journalists tend to see themselves as active watchdogs, but a misalignment exists between perception and actual behavior. Journalists claim that they report to the public, but when asked in more detail, they are writing for wealthy, male, well-educated business people or citizens with a strong interest in investments. Strauß (2019) notes, similarly to Usher (2012), that business journalists prefer speaking to an elite audience. Furthermore, they have been accused of promoting the "cult of the chief executive," which has created an almost mythic status for managers in corporate culture and enabled extremely high salariesanother manifestation of neoliberal business philosophy (Butterick, 2015, pp. 127-129).

Strauß (2019) calls for a new modern watchdog role of business journalism: fair, objective, and reliable educator and informant for the general public. She sees this as a challenging task due to decreasing resources in the newsrooms: There are fewer editors and less collegial mentoring and educating younger reporters which might lead to lower quality in reporting and a deterioration in ethics and journalistic values. However, business journalism has also taken in a stronger audience orientation. While in traditional business journalism large companies are being discussed more than small ones, the trend has turned towards more personality-driven storytelling: Interesting people and businesses are more attractive to readers, and well-known companies, like those in retail business, gather more traffic. Critics argue that the concentration on interesting individuals diverts attention from more important and substantial issues. (Butterick, 2015, p. 122.)

\subsection{Business Journalism in the Nordic Countries}

The Nordic countries can be seen as a relatively homogenous region economically, politically, and culturally, which correlates to their mass media (Byrkjeflot, 2001; Hallin \& Mancini, 2003; Slaatta \& Kjær, 2007). These countries are highly developed capitalistic economies with parliamentary democracy, welfare-state regimes, and uniform national cultures. Simultaneously, however, the Nordic countries seem a challenging market to business journalism; as their awareness of social welfare and national economic policies is highly developed, there are strong traditions of economic regulation, and, in general, commercial mass media has been relatively weak (Slaatta \& Kjær, 2007).

According to Hallin and Mancini (2003) professionalism is affected by different national media systems. The Nordic and Central European media model-the democratic corporatist model-is characterized by the strong and early development of journalistic professionalism (Hallin \& Mancini, 2003, p. 143), implying that journalists in this system have adopted relatively similar traditions and attitudes. Syvertsen et al. (2014) gather these into a Media Welfare State model, a set of organizational values and beliefs that align similarly with the more general economic and social terms of the welfare state. Although many developments, like increasing commercialization, have taken place in the Nordic media landscape, compared internationally, Nordic journalists in general are still characterized by a welfare state mentality (Ahva et al., 2017).

The development of modern business journalism in Nordic countries has coincided with many changes in the market since the 1960s. The postwar consensus of the welfare states began falling apart, and neoliberal and microeconomic ideas started rising. The financial and industrial elites saw that certain business interests needed to be communicated to shape public opinion, and business journalism served as the means. Business news increased greatly, many new media outlets were founded, and a new kind of neoliberalist criticism towards the welfare state and interventionist policies grew in the Nordic countries (Slaatta \& Kjær, 2007, pp. 13-26). Hence, the development of Nordic business journalism is not totally parallel to the region's journalism in general but creates an interesting combination of ideologies.

At first, business journalism met skepticism among journalists and was seen as little more than free advertising. It was also difficult to find journalists that were competent enough to report on business matters and some business news outlets started to train business and 
economics graduates to journalists while others chose to train on-the-job journalists to report knowledgeably on business and economics. Due to their background, the latter group had a stronger understanding of journalistic norms, but both affected the development of the profession (Grafström, 2006; Kjær, 2009, p. 77).

While business journalism in Western countries is generally produced to the business elite, the Nordic business journalists saw themselves early on rather as reporting on behalf of a broader public. During the years from the 1960 s to 1980 s, when the field was developing fast, this idea transferred into journalism with tabloid-like features: empathizing drama in business with large pictures and headlines. From the 1980s, business journalists started practicing more investigating ideals of journalism and concentrated on newsworthy companies and events. This development led to the acknowledgment of business journalism as a professionalized field inside journalism also in Nordic countries (Kjær, 2009, pp. 78-79).

\section{Research Data and Method}

The empirical case study concentrates on editors of four Nordic business newsrooms: Kauppalehti in Finland, Börsen in Denmark, Dagens Industri in Sweden, and Dagens Näringsliv in Norway. These media outlets provide a homogeneous field of study: they have similar market positions in their countries; substantial editorial departments; and large, targeted audiences in both print and digital. Although they are leading business news providers in their markets, they have faced turbulent years, as have all legacy news organizations.

Dagens Industri is clearly the newest of the publications, founded in 1976, when business news was increasing rapidly in Nordic societies. The three other publications have century-long histories with close connections to the business life of their markets. For instance, Kauppalehti was originally the "tribune for businessmen" and Dagens Näringsliv the newspaper for the seafaring industry, later adding all business to its scope. They all declare to be (economic) liberal or liberal-conservative. Kauppalehti is the only one owned by a publicly listed company, Alma Media Oyj.

To answer the research question, I conducted a series of face-to-face semi-structured interviews (total of 20) with news editors and managing editors in these four newsrooms. Also, three editors-in-chief were included. Interviews took from 40 to 75 minutes, from April through June 2018. Every interview was recorded, transcribed, and further analyzed in accordance with the thematic analysis.

In the interviews, I asked the editors to describe their careers: how and why they joined the profession, what they thought was good journalism initially, and how those ideas have prevailed or changed. The aim was to observe signs of shifts in the ethical framework. Second, I invited the editors to describe how journalism is produced every day in their newsroom, what is the driving force in their work, what makes them feel a job is well done, and what they do if they do not reach what they are after. With these questions, I was able to picture how the editors perceive their everyday work.

The goal was to identify what the editors saw as modern-day "virtues," cultured practices of everyday work, to pursue a job well done, but it is worth noting that this is how the editors find their work and the actual practice might differ from this, like earlier research has shown (e.g., Wiik, 2015). Journalism as a profession finds its ethics in work practices, which is why changes of profession have often been examined by studying the transformation of everyday journalistic work.

In the thematic data analysis, I first collected all notions where editors' descriptions of their work mirrored traditional journalistic values and then those reflecting more managerial values. This provided a combined representation of what editors saw as the ideal demeanor for an editor. After this, I grouped the descriptions into categories: "managerial ideals," "journalistic ideals," "me as a manager," and "me as a journalist." Through these categories, I could find different aspects of the editors' ethos. Finally, I divided the whole material into four groups by country to assess differences between the newsrooms, though on the surface there were none.

\section{Results}

During the news industry's recent volatile years, newsroom management, the editors, have faced the biggest changes in their work: In addition to good journalism, editors must understand the business of news and manage news production accordingly. In business news, editors have a solid understanding of market economy ideas but also long journalistic careers, tight connections to their professional community and its values, and a strong mission of public service. As a result of the interviews, I gather here four sets of ideals that appear in the editors' work: they appreciate the position of a manager and see management as important; they find efficiency and results valuable; they value the public service role of journalism though the connotation is changing; and preserving autonomy and self-regulation of the profession qualifies the editors to supervise journalists. This set of ideals creates a new, negotiated professional ethos of a business news editor.

\subsection{Qualifications of a Manager}

In my interviews, I met seasoned newsroom managers, ages $35-55,70 \%$ men. They usually had an academic education in journalism but also in politics, economics, or political history. Most became journalists due to their interest in societal or economic matters, but some had landed in journalism only by will and talent to write.

Most editors interviewed had long careers as business journalists, and many seemed to have suitable qualities to become managers. They described wanting 
to carry more responsibility for planning and developing the work, organizing, and supervising others-activities promoting improved performance, which managerialism emphasizes:

I'm a pretty decent journalist but I'm probably more talented as a manager. So that was always, quite early, I like to boss people around. And I realized I can actually get more done by trying to train a whole newsroom. (Interviewee 4)

Although some of the editors drifted into management, most were conscious of what the managerial role demands and, early on in their careers, noticed that they possessed those qualities. Editors are comfortable with the overseeing and supervising role in the newsroom and see it as increasingly important in splintered online media. They talk about "the product" or "the brand" which they are producing as efficiently as possible:

You...have to get all these individuals to work together. Perhaps that's one of the things that I like to do and what I'm good at....At the paper you have a lot of superegos but then it's the product that you are, that gets the results. It's not the egos, but you need egos, and you need all the other ones as well to get a good product. (Interviewee 5)

The editors' willingness to manage shows that, from this perspective, journalism has similarities to any other business, as managerialism indicates. The same demands of efficiency, target setting, and teambuilding exist in the newsroom. When editors manage newsrooms with undisputed performance indicators, they represent one of the key qualities of managerialism: it is rationalthat is, value-neutral. Journalism, earlier produced only with "gut feeling," becomes a logical, rational, measurable performance.

Business news editors share the values of market economy, which seems to support absorbing businesslike work manners: working next to and with the business community and reporting on its issues is an inspiring resource of more-efficient practices. In addition, the editors believe that business journalists in general accept performance indicators and want to know how the business of the organization is going. While this is only an assumption, and actual perception of the new, resultsoriented practices might vary, the values by which a newsroom is managed evidently affect what is considered a job well done and how business journalists experience their profession.

\subsection{The Ideal of Efficiency and Results}

In addition to managing daily news production, editors are increasingly responsible for the outcomes of the newsroom, particularly for reaching audience objectives. Following readers' preferences through online analyt- ics defines the day, and news work is conducted consciously to reach desired results. As one described her daily job: "What are main stories, how the headlines are edited, how the stories are served, how they are packaged, how do we get them as large audience as possible" (Interviewee 1).

Earlier, the editors oversaw the prioritized agenda of the day, which was printed in the newspaper. Now the focus is shifting towards news promotion. Though actual reporting follows traditional practices, stories go through new kinds of promotional processes like any other merchandise: they are edited, marketed, and optimized to achieve their full potential in every channel. Outcomes are explicit when they can be observed in metrics.

Although the reasoning is clear, working by and for the numbers is stressful for editors. Many find the work denser, with pressure for traffic and subscriptions higher than ever. The work happens faster, and there are many new aspects to consider when deciding what to publish. There is also constant concern about being boring if the news selection is done according to only "old" news criteria:

Decisions need to be made more quickly. And you can't go only with that, ok, this [topic] has a great societal value and meaning, this has to be reported well. You have to think of the input-output relation. But I guess it has always been like that but now there are more aspects, things that impact the decisions, if there used to be three or four, now there are 10-12, and you have to prioritize. (Interviewee 9)

This is very complex. The old regime was that there was a simple truth, and we tell it, we take care of it, but now we really don't know, and we can't always tell what is interesting to the readers. (Interviewee 19)

The immediate response to publishing decisions in online channels is welcomed, but many editors reminisce about print-only times when they got reader statistics only once or twice a year. In the present day, when the workday is run by numbers, editors seem to have lost some control over their work, and, furthermore, some of them feel constantly anxious about coping with the new demands. But the concern also reveals that these metrics are important to the editors and high-performance results are valuated:

We have this constant anxiety if we have enough traffic, do we have sufficiently stories, are they good enough. This has changed so that it is constant, that worry, that something bad is going to happen, or that things do not go as they should....When in the morning we already see that now this goes wrong, and we try to react, but usually it goes that we do not get hold of it, so it is terrible and that way it is excruciating to follow those figures, so that it really makes a normal person grey. (Interviewee 6) 
Comparing the four newsrooms, the editors who mainly oversaw production of the print edition felt less stress over the results-they still lived in the "stress-free print era." Correspondingly, editors supervising an entire newsroom or online news production expressed more stress over productivity and outcomes. In Kauppalehti, where editors expressed the most stress over results and were notably aware of the business aspirations of their company, figures seemed to have the biggest role, maybe because it is a publicly listed company.

\subsection{The Ideal of Public Service and Objectivity}

The editors feel strongly that they work for their readers, for the public. They have a strong sense of public service ideals or even an educational role of journalism: The editors want to report to the public "how and where wealth is created in society" or show "how objectively produced information changes markets" (Interviewees 6 and 19). Although business journalism is claimed to be for everyone, the described primary readers are typical for the business press: well-educated managers, entrepreneurs, or investors with high income. Similarly to other Western societies, business journalism in Nordic countries is journalism to the elite.

Public service once meant helping citizens operate consciously in society, but now audiences seem to have shifted to more active but privatized "consumerists" (Ahva, 2010; Hanitzsch, 2007). As noted earlier (Andersson, 2009; Andersson \& Wiik, 2013), journalists talk about readers, but editors apply the term "customer" to describe their audience. Like general news, business journalism has moved in a more consumerist direction. Newsrooms provide their subscribing customers "premium" content that is useful to the reader, and public service is also described as "giving investment pointers." The public service ideal remains, but there is a shift towards customer-centricity; whereas citizens are provided information needed in democratic decision-making, consumers are offered tips and directions to manage everyday life-in business journalism, their commercial, professional, and financial life:

Ten years ago, when I started as a...news editor we were very focused on big news, sometimes scandals, sometimes breaking news, and we are still that, but we are also very focused...to help our readers and subscribers to make good decisions at work or at home. (Interviewee 5)

The area of journalism that was the mouthpiece of the industrial and financial community, particularly in postwar Nordic societies, has now turned towards the single consumer, following the same trend as journalism and society overall. Nonetheless, this change relates to audience-centricity, which has been accelerated by developing traffic analytics and the need for growing numbers of readers (see Butterick, 2015). This is causing ethical discussions: whether to produce highend financial journalism to the business elite or more everyday-focused service journalism to "blue-collar men and women in business," as one interviewee put it.

Some of the editors find the new "interesting" news criteria somewhat objectionable. Traditionally business journalism has concentrated on reporting about large companies with a critical outlook on performance indicators. Now stories are more personality-driven and about intriguing companies of all sizes. The old, objective, and critical stance in news selection gives to some extent room to "business entertainment" and this bothers some of the editors.

\subsection{Autonomy and Self-Regulation of the Profession}

Even if editors' power over news production has increased, the strong collegial support and control, shared values and ethics of the profession, and sense of journalistic community preserves as a foundation relied on to claim occupational authority. Autonomy is still attained by the strong value system of journalism and self-regulation among journalists.

Editors speak highly of the collegial community and its ability to steer news work back on track. For instance, high-end financial journalism and "popular" topics require continuous negotiation, and certain stories get published even though they are estimated not to bring that much traffic. Many editors also trust that their long career in business news gives them a gut feeling of what "the brand," - the promise to the readers-is and what it entails. Many say they have learned from mistakes made when the online channel and audience metrics were new. At that time, journalism was under threat of becoming too commercially led, and even its reliability was questioned because of so-called click journalism.

Journalistic ethics are the solid ground on which the editors build their managerial role. Hints of managerial behavior are accepted in the newsroom when the editor is foremost a journalist. Journalistic work experience is a highly legitimizing factor to lead journalists (see Waldenström et al., 2019, p. 13); it balances the ethos of journalistic collegial control and the accountability of managerial ruling. As one editor described it: "The editor needs to be there, go along, be a part of the team - then it works. If the journalists do not rely on their management, they start acting out some way, and that can be quite brutal" (Interviewee 2).

The editors also need to ride on two horses when motivating reporters to be both good journalists with high ethics and productive news workers with measurable results. Earlier, a reporter wrote as one of many journalists without really seeing what their input was worth to the outlet; now everyone's performance is ranked daily. The feedback came from peers, family, or friends; now it comes from clear numbers. As managers, the editors see this as a challenge. They meet a value cap where once were journalistic ideals: 
You can't ignore that there's an element of competition, that it's, of course, for a reporter, on a good day he or she gets another high...if they're having a bad day, of course, it's much tougher. Sometimes we [editors] have been forced to...[say], this is what happens, but it doesn't mean that this is a better article, it's just selling more, and it doesn't mean that you're a lousy reporter because no one actually cares about this [your story]. (Interviewee 9)

Explaining what it is to be a good journalist today, and what is expected from a reporter, might be one of the most demanding tasks in editors' work. Considering that journalism is a profession without formal qualifications, preserving certain boundaries is crucial to protect the occupational authority journalists hold. When supervising news work, the editors must carefully consider when to elevate journalistic autonomy and when to press business goals.

\section{Conclusions}

In this article, I examined how Nordic business news editors combine managerial practices with their journalistic professional ethos. The interviews show how editors negotiate managerial and journalistic work practices and how managerial ideals are blended with virtues of journalism. Together, they create the professional ethos of editors.

The professional ethos of editors, what editors want to be but also need to be, is a combination of ideas from journalism and managerialism. The editors in business news media are notably well equipped to be managersthey have the qualifications and the trust in market economy, and they see management to be important. However, there is still a strong sense of journalistic ethos and professional community. The editors must be and want to be a visible and dependable part of the journalistic profession.

The editors create new hybrid professional ideals. In pure managerialism, policies of good management are enough to justify managers' autonomy (Pollitt, 2003), but as news managers, editors must also integrate journalistic ideals into it (Shepherd, 2018). While the editors have will and talent to manage people, to earn the right to manage and the social status of manager in the newsroom, editors must also be good journalists. Furthermore, editors believe that quantitative evaluations and journalistic ambitions can coexist; it is a demanding job to combine them, but these are professionals of news work management. Also, Saldaña et al. (2016), Raviola (2017), and Cornia et al. (2020) have made parallel observations. The most challenging role editors have as an interpreter between these two sets of ideals: how to encourage reporters to be the best journalists but also produce the best measurable outcomes.

As earlier research has shown (Anderson \& Wiik, 2013; Cornia et al., 2020; Waldenström et al., 2019), edi- tors legitimize change in the newsroom as a necessity to keep producing quality journalism. Alternatively, emphasizing performance indicators can be a shield against pressure from the business side: By communicating with figures, editors are neutral professionals who can be trusted to manage newsrooms in an impersonal way with the company's best interests in mind. Performance indicators are a good calling card for editors, justifying their autonomy and legitimizing their authority over the journalism they lead, which is why editors are notably committed to them. The figures are neutral and free of values: if they are good, I am a good editor.

The journalistic professional ethos is transforming, along with the profession's work practices in a changing mediascape, but changes differ by journalistic field. There are differences between general and specialized journalism and even inside one specialized journalism group (Jaakkola et al., 2015, p. 824). In business journalism, the distinctive feature is familiarity with managerial manifestations. Business journalists have promoted market economy ideals in society alongside close encounters with the surrounding business community (Butterick, 2015; Mazza \& Alvarez, 2000; Slaatta \& Kjær, 2007); therefore, it is logical that managerialism has more potential to infiltrate business journalism practices than those in other areas of journalism. The editors, too, seem to assume this.

In the case of business journalism, the ideal of public service has had a unique tone because the business press has concentrated on reporting to the financial and commercial elite in society. Now the increasing demand for commercial success requires editors to turn to more "general" financial reporting and service journalism to the masses. This new, more audience-oriented journalism can bring business journalism closer to the general public, which might benefit from more informative and educational reporting. This could be a modern-day watchdog role, as Strauß (2019) suggests, and an interesting development in the professionalization of business journalism. But is this a continuing development, and if so, where does it take business journalism in the media system?

Journalism as a profession makes its claim on occupational authority by distancing itself from business considerations (Schudson \& Anderson, 2009), but editors are on the frontline of increasingly business-like demands in the newsroom. Business competence is expected from the editors (Achtenhagen \& Raviola, 2007; Gade, 2008), but for business journalists, this is probably easier to accept than for others. Managerial work practices might help newsrooms operate more efficiently, and by reporting the outcomes business-style, the editors are able to show they are doing their part in the tightened economic situation.

Editors experience changes in news work differently from reporters, as their daily work concentrates on the whole news organization. It is no wonder that the professional ethos of an editor diverges from the reporter 
and reshapes into a hybrid ethos. The new hybrid ethos of editors was noted by Kunelius and Ruusunoksa (2008), and it can be observed as part of journalism's becoming a more "liquid" profession with an increasingly plastic, multiskilled, and highly manageable workforce (Deuze, 2005, 2007; Kantola, 2016, pp. 425-426). This development has become faster, with online news and heightened pressure for measurable results, and needs further research in the future.

\section{Acknowledgments}

This research was funded by the C. V. Åkerlund Media Foundation.

\section{Conflict of Interests}

The author declares no conflict of interests.

\section{References}

Abramov, R. N. (2012). Managerialism and the academic profession: Conflict and interaction. Russian Education and Society, 54(3), 63-80. https://doi.org/ 10.2753/RES1060-9393540304

Achtenhagen, L., \& Raviola, E. (2007). Organizing internal tension: Duality management of media companies. In L. Achtenhagen (Ed.), Organizing media: Mastering the challenges of organizational change. JIBS research reports (pp. 127-146). Jonkoping International Business School.

Ahva, L. (2010). Making news with citizens: Public journalism and professional reflexivity in Finnish newspapers. Tampere University Press.

Ahva, L., van Dalen, A., Hovden, J. F., Kolbeins, G. H., Löfgren Nilsson, M., Skovsgaard, M., \& Väliverronen, J. (2017). A welfare state of mind? Nordic journalists' conception of their role and autonomy in international context. Journalism Studies, 18(5), 595-613. https://doi.org/10.1080/1461670X.2016.1249005

Ainamo, A., Tienari, J., \& Vaara, E. (2006). Between West and East: A social history of business journalism in Cold War Finland. Human Relations, 59(5), 611-636. https://doi.org/10.1177/0018726706066550

Andersson, U. (2009). Journalists' attitudes to readership studies: A study of newspaper journalists and editorsin-chief in Sweden. In Y. Pasadeos (Ed.), Variety in mass media communications (pp. 9-20). ATINER.

Andersson, U., \& Wiik, J. (2013). Journalism meets management. Journalism Practice, 7(5), 705-719.

Aris, A., \& Bughin, J. (2009). Managing media companies: Harnessing creative value ( 2 nd ed.). Wiley.

Aristotle. (1991). On rhetoric: A theory of civic discourse. Oxford University Press.

Butterick, K. (2015). Complacency and collusion: A critical introduction to business and financial journalism. Pluto.

Byrkjeflot, H. (2001). The democratic challenge to capital- ism: Management and democracy in the Nordic countries. Fagbokforlaget.

Carpentier, N. (2005). Identity, contingency, and rigidity: The (counter-)hegemonic constructions of the identity of the media professional. Journalism, 6(2), 199-219.

Clarke, J., Gerwitz, S., \& McLaughlin, E. (2000). New managerialism, new welfare? SAGE.

Coddington, M. (2015). The wall becomes a curtain. In M. Carlson \& S. C. Lewis (Eds.), Boundaries of journalism: Professionalism, practices, and participation (pp. 67-82). Routledge.

Cornia, A., Sehl, A., \& Nielsen, R. K. (2020). "We no longer live in a time of separation": A comparative analysis of how editorial and commercial integration became a norm. Journalism, 21(2), 172-190. https://doi.org/ $10.1177 / 1464884918779919$

Davis, A. (2007). The mediation of power: A critical introduction. Routledge.

Deuze, M. (2005). What is journalism? Professional identity and ideology of journalists reconsidered. Journalism: Theory, Practice \& Criticism, 6(4), 442-464.

Deuze, M. (2007). Media work: Digital media and society series. Polity.

Diefenbach, T. (2009). New public management in public sector organizations: The dark sides of managerialistic "enlightenment." Public Administration, 87(4), 892-909.

Doyle, G. (2006). Financial news journalism: A post-Enron analysis of approaches towards economic and financial news production in the UK. Journalism, 7(4), 433-452.

Engwall, L., \& Kipping, M. (2002). Management consulting: Emergence and dynamics of a knowledge industry. Oxford University Press.

Entemann, W. F. (1993). Managerialism: The emergence of a new ideology. University of Wisconsin Press.

Gade, P. J. (2008). Journalism guardians in a time of great change: News editors' perceived influence in integrated news organizations. Journalism \& Mass Communication Quarterly, 85(2), 371-392.

Grafström, M. (2006). The development of Swedish business journalism: Historical roots of an organisational field. Företagsekonomiska institutionen, Uppsala Universitet.

Hallin, D. D., \& Mancini, P. (2003). Comparing media systems: Three models of media and politics. Cambridge University Press.

Hanitzsch, T. (2007). Deconstructing journalism culture: Toward a universal theory. Communication Theory, 17(4), 367-385.

Hanitzsch, T., Hanusch, F., \& Lauerer, C. (2016). Setting the agenda, influencing public opinion, and advocating for social change: Determinants of journalistic interventionism in 21 countries. Journalism Studies, 17(1), 1-20.

Hanitzsch, T., \& Vos, P. T. (2017). Journalistic roles and the struggle over institutional identity: The discur- 
sive constitution of journalism. Communication Theory, 27(2), 115-135.

Hujanen, J. (2008). RISC monitor audience rating and its implications for journalistic practice. Journalism, 9(2), 182-199.

Jaakkola, M., Hellman, H., Koljonen, K., \& Väliverronen, J. (2015). Liquid modern journalism with a difference: The changing professional ethos of cultural journalism. Journalism Practice, 9(6), 811-828.

Kantola, A. (2013). From gardeners to revolutionaries: The rise of liquid ethos in journalism. Journalism, 14(5), 606-626.

Kantola, A. (2016). Liquid journalism. In T. Witschge, C. W. Anderson, D. Domingo, \& A. Hermida (Eds.), The SAGE handbook of digital journalism (pp. 424-441). SAGE.

Kjær, P. (2009). Expansion and autonomy: The rise of the business press. In L. Chouliaraki \& M. Morsing (Eds.), Media, organizations and identity (pp. 70-92). Palgrave Macmillan.

Klikauer, T. (2015). What is managerialism? Critical Sociology, 41(7/8), 1103-1119. https://doi.org/10.1177/ 0896920513501351

Kunelius, R., \& Ruusunoksa, L. (2008). Mapping professional imagination. Journalism Studies, 9(5), 662-678.

MacIntyre, A. C. (1984). After virtue: A study in moral theory. University of Notre Dame Press.

Maringe, F. (2010). The meanings of globalization and internationalization in higher education: Findings from a world survey. In F. Maringe \& N. Foskett (Eds.), Globalization and internationalization in higher education: Theoretical, strategic, and management perspectives (pp. 17-34). Continuum.

Mazza, C., \& Alvarez, J. L. (2000). Haute couture and prêt-à-porter: The popular press and the diffusion of management practices. Organization Studies, 21(3), 567-588. https://doi.org/10.1177/0170840 600213004

Nikunen, K. (2014). Losing my profession: Age, experience, and expertise in the changing newsrooms. Journalism, 15(7), 868-888.

Orange, R., \& Turner, B. (2013). Specialist journalism. Routledge.

Picard, R. (2006). Journalism, value creation, and the future of news organizations. Joan Shorenstein Center on the Press, Politics and Public Policy.

Pollitt, C. (2003). The essential public manager. Open University Press.

Raviola, E. (2017). Meetings between frames: Negotiating worth between journalism and management. European Management Journal, 35(6), 737-744.

Reunanen, E., \& Koljonen, K. (2018). Not partisans, but participants: The quantity and quality of journalistic interventionism in Finnish journalists' professional ethos. Journalism Studies, 19(5), 726-744.

Saldaña, M., Sylvie, G., \& McGregor, S. C. (2016). Journal- ism: Business tension in swedish newsroom decision making. Journal of Media Ethics, 31(2), 100-115.

Schiffrin, A. (2015). The press and the financial crisis: A review of the literature. Sociology Compass, 9(8), 639-653. https://doi.org/10.1111/soc4.12288

Schudson, M. (2009). Ten years backwards and forwards. Journalism, 10(3), 368-370.

Schudson, M., \& Anderson, C. (2009). Objectivity, professionalism, and truth seeking in journalism. In $\mathrm{K}$. Wahl-Jorgensen \& T. Hanitzsch (Eds.), The handbook of journalism studies (pp. 88-101). Routledge.

Schultz, I. (2007). The journalistic gut feeling: Journalistic doxa, news habitus and orthodox news values. Journalism Practice, 1(2), 190-207.

Sennett, R. (2008). The craftsman. Penguin.

Shepherd, S. (2018). Managerialism: An ideal type. Studies in Higher Education, 43(9), 1668-1678. https:// doi.org/10.1080/03075079.2017.1281239

Slaatta, T., \& Kjær, P. (2007). Mediating business: The expansion of business journalism. Samfundslitteratur.

Strauß, N. (2019). Financial journalism in today's highfrequency news and information era. Journalism, 20(2), 274-291. https://doi.org/10.1177/14648849 17753556

Syvertsen, T., Mjøs, O. J., Moe, H., \& Enli, G. S. (2014). The media welfare state: Nordic media in the digital era. University of Michigan Press. https://doi.org/ 10.2307/j.ctv65swsg

Thompson, P. A. (2013). Invested interests? Reflexivity, representation, and reporting in financial markets. Journalism, 14(2), 208-227.

Tienari, J., Vaara, E., \& Erkama, N. (2007). The gospel according to the global market. How journalists frame ownership in the case of Nokia in Finland. In T. Slaatta \& P. Kjær (Eds.), Mediating business: The expansion of business journalism (pp. 187-214). Samfundslitteratur.

Usher, N. (2012). Ignored, uninterested, and the blame game: How The New York Times, Marketplace, and TheStreet distanced themselves from preventing the 2007-2009 financial crisis. Journalism, 14(2), 190-207.

Waisbord, S. (2013). Reinventing professionalism: Journalism and news in global perspective. Polity.

Waldenström, A., Wiik, J., \& Andersson, U. (2019). Conditional autonomy: Journalistic practice in the tension field between professionalism and managerialism. Journalism Practice, 13(4), 493-508. https://doi. org/10.1080/17512786.2018.1485510

Wiik, J. (2010). Journalism in transition. University of Gothenburg.

Wiik, J. (2015). Internal boundaries: The stratification of the journalistic collective. In M. Carlson \& S. C. Lewis (Eds.), Boundaries of journalism: Professionalism, practices, and participation (pp. 118-134). Routledge. 


\section{COGITATIO}

\section{About the Author}

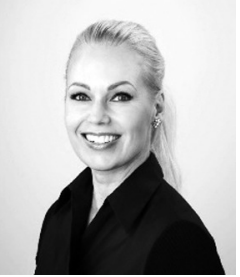

Johanna Suhonen is a doctoral candidate of media and communication studies at the Faculty of Social Sciences at the University of Helsinki, where she is currently working on her dissertation on professional development of business journalism in the Nordic countries. She also holds the position of commercial director at media company Alma Media Oyj in Helsinki, Finland. 